\title{
Revenue Diversification Within Metropolitan Areas: Effects On Disparities And Central City-Suburban Fiscal Relationships
}

\author{
John H. Bowman and John L. Mikesell*
}

Even before California's Proposition 13 intensified the property tax revolt in 1978, there was pressure to diversify local tax structures by opening income and/or sales taxes to local units. Various motives for revenue diversification include the desire to give people a greater choice of tax form-to substitute non-property taxes-and the desire to enable local units to raise more money-to augment the property tax. Even a relative shift toward non-property taxation has the capability either to ease or to aggravate some important intra-urban fiscal relationships.

Local non-property taxes have been of increasing importance since their introduction in the 1930s. By 1977-78, some local units in 27 states had general sales tax revenues, while local units in 10 states had income tax revenues. [Bureau of the Census, 1980, Table 5] Overall, these major local non-property taxes raised nearly $13 \%$ of all local taxes $(5.1 \%$ income, $7.7 \%$ general sales), versus over $80 \%$ for the property tax. [Bureau of the Census, 1980a, p. 4] For some units, especially large cities, income and sales taxes contribute larger shares of total local taxes $(19.1 \%$ and $14.0 \%$, respectively, for the 46 largest cities in 1977-78). Of these cities, 25 had a general sales tax and 13 had an income tax. [Bureau of the Census, 1980b, Table 8] The view that the significance of such revenue is likely to continue to increase is supported by past experience, the mounting dissatisfaction with the property tax, and a relaxing of sentiment against local nonproperty taxes. ${ }^{1}$

As central city-suburban fiscal relationships remain strained, it is appropriate to consider the impact of increasing reliance upon local income and sales taxes within urban areas. Especially important questions in that environment include:

1. Are tax base disparities among local units in a metropolitan area greater or less for income and sales taxes than for property taxes?

2. Are property and non-property tax base disparities within the region additive or off-setting?

*Senior Fellow, Economics and Public Finance, Academy for Contemporary Problems and Professor, School of Public and Environmental Affairs, Indiana University-Bloomington. We wish to acknowledge suggestions by Frederick D. Stocker that were helpful in the development of the research reported here, and comments by John Jakubs and Richard L. Pfister on a draft of this paper. 
3. Are central city-suburban fiscal relationships different under income and sales taxes from those found under property taxes?

4. Are local income and sales taxes more or less equalizing with respect to income than property taxes?

Urban fiscal policy requires information on these and similar questions. In the existing research, the important comparison between property and non-property taxes seldom is made; hypothetical tax structures, rather than actual institutions, often are studied, even though the differences

\section{TABLE 1.}

Correlations Between Per Capita Income of Residents and Per Capita Property and Non-property Tax Bases For Municipalities In Two Income Tax And Two Sales Tax SMSAs*

\begin{tabular}{ccc}
\hline $\begin{array}{c}\text { Per capita } \\
\text { income }\end{array}$ & $\begin{array}{c}\text { Per capita non- } \\
\text { property tax base** }\end{array}$ & $\begin{array}{c}\text { Per capita } \\
\text { assessed value }\end{array}$ \\
\hline
\end{tabular}

\section{Cincinnati}

Per capita income

Municipal income tax SMSAs

Per capita income tax base

Per capita assessed value

$$
.196 \#
$$

Cleveland

Per capita income

Per capita income tax base

Per capita assessed value

$$
.013 \# \# \quad .992
$$

Municipal sales tax SMSAs

San Francisco-Oakland

Per capita income

Per capita sales tax base

Per capita assessed value

$-.044$

.078

Per capita income

Per capita sales tax base

Per capita assessed value
.012

.038
.949

1.0
1.0

.992
1.0

*Tax base figures are four-year averages; residents' income figures are for 1974.

**Income tax base for Cincinnati and Cleveland SMSAs, sales tax base for Los Angeles-Long Beach and San Francisco-Oakland SMSAs.

\#Correlation for all municipalities, including income tax non-adopters, is .263.

\#\#Correlation for all municipalities, including income tax non-adopters, is .033.

SOURCE: See text. 
may be striking; where actual tax data are used, they generally are taken for only one year, leaving the possibility of aberrations affecting the results; and the units studied often are counties, rather than municipalities. Before turning to our research, it is appropriate to review some of the earlier works. Because of the present concern with intra-urban area relationships, studies examining countywide fiscal disparities across a state are excluded.

\section{Earlier Studies}

Municipal income taxes in a metropolitan setting were studied by Stephens in a 1969 paper. [Stephens, 1969, pp. 313-333] Using a large amount of census data, he constructed a model of a hypothetical metropolitan area to study the differences in per capita tax revenues for various types of communities under alternative municipal income tax structures. Not surprisingly, he concluded that some suburban communities would get more (and others less) revenue per capita than the central city under any form of local income tax other than one available only to the central city. The central city's revenue would be maximized under a tax imposed on both a residence and an employment basis, without reciprocity. This study is weakened by the absence of property tax comparisons and by its hypothetical nature, featuring, as it does, "a more or less average core city" and eight suburban municipalities of "extreme types rather than typical suburban units ... to heighten the differential impact upon the individual governments." [Stephens, 1969, p. 314]

In a 1976 paper, Stocker used actual 1972 income tax data for selected municipalities in Ohio. [Stocker, 1976, pp. 312-321] Comparisons were made between residents' money incomes and municipal income tax bases. For each of the eight largest cities, the actual tax base per capita was greater than its residents' per capita income (the Ohio taxes generally conform to the model Stephens found to be most productive of city revenue), with the ratios ranging from 1.27 to 2.36 . Looking at selected taxing municipalities within the three largest counties, however, he found some suburban communities-industrial or commercial enclaves-with still more favorable ratios (as high as 24.96), while the residential bedroom communities had ratios below 1.0. [Stocker, 1976, pp. $316-317$ ] Central city-balance of SMSA hypothetical sales tax comparisons were made for the nation's largest retail trade centers in 1972; the ratios of per capita sales in the central city to per capita sales in the rest of the SMSA's were below 1.0 (suburbs fare better) in seven cases and above 1.0 in eight, with the range being from .76 to 1.95. [Stocker, 1976, pp. 318-319] While this study includes both municipal income and sales taxes, it does not directly compare the two either to each other or to the property tax. Moreover, it includes no measures of disparities among jurisdictions. Finally, in the sales tax case the suburbs' data were highly aggregated and did not reflect actual taxes.

The three major local taxes were directly compared for cities in Los Angeles County in FY 1970 by Reischauer. [Reischauer, 1975, pp. 288306] Listing per capita tax bases for all three types of taxes, he found the 
range of per capita base disparities smallest for the income tax (liability to residence community) and largest for the sales tax, with the property tax between them. [Reischauer, 1975, pp. 302-303] This research is better suited to answering the questions we pose here than the other studies summarized, but it still lacks actual income tax data (the hypothetical tax studied is residence based, not the more common employment-based type) and uses data for only one year (which may or may not be typical). Moreover, it explicitly addresses only the first of the four questions we presented above.

\section{Intra-Metropolitan Analysis}

The significant central city-suburb fiscal relationships issues can be considered only by analysis of individual municipalities within selected metropolitan areas, for most local taxes are raised by such sub-county units. The metropolitan area focus is important because of the continuing problems of fiscal imbalance within such areas, and because most people live in metropolitan areas. Moreover, local non-property taxes tend to be adopted first in metropolitan areas, perhaps because of their relatively greater public expenditure needs. In this setting, tax relationships may well be different from those presented in inter-county studies. Stocker has observed that, " $(\mathrm{O})$ ne of the most significant features of a municipal income tax is its ability to suck revenue out of the suburbs and into the central city especially where the income tax applies alike to the income of nonresidents and residents, ..." [Stocker, 1976, p. 315] Thus, local nonproperty taxes may help overcome central city-suburban fiscal imbalance.

The local income taxes studied here are those of Ohio municipalities in the Cincinnati and Cleveland SMSAs, where the taxes apply on the bases of both residence and employment, and without reciprocity-in short, the sort of tax which Stephens' work suggests will be most productive for central cities. The sales taxes of municipalities in Los Angeles-Long Beach and San Francisco-Oakland SMSAs are studied.

\section{Ohio Municipal Income Taxes}

The Ohio municipal income tax movement began with Toledo's adoption in 1946 , and in 1977 this source provided over $\$ 600$ million revenue to the more than 400 income tax municipalities. Since 1957 , state statute has provided the ground rules for such taxes, including the requirement of approval by the local electors for any rate in excess of $1.0 \%$ and the prohibition of graduated rates. Over half the income tax municipalities levy at the $1.0 \%$ rate, although the rates range from $0.25 \%$ to $2.0 \%$. The taxes typically apply to all earned income of residents, non-residents' income earned within the taxing unit, and net business (including corporation) income attributable to activities within the taxing unit. [Ohio Department of Taxation, 1978b, pp. 35-37] However, "(M)ost municipalities allow a partial or full credit to residents for taxes paid to the municipality of employment," [Ohio Department of Taxation, 1978a] making the tax essentially employment based, the typical form of local income tax. 
TABLE 2.

Comparisons Of Per Capita Income Of Residents And Per Capita Property And Non-Property

Tax Bases For Municipalities In Two Income Tax And Two Sales Tax SMSAs*

\begin{tabular}{|c|c|c|c|c|c|c|c|}
\hline & Mean & Median & Minimum & Maximum & $\begin{array}{c}\text { Ratio: } \\
\text { Maximum/ } \\
\text { minimum }\end{array}$ & $\begin{array}{l}\text { Ratio: } \\
\text { Fifth from } \\
\text { top/fifth } \\
\text { from bottom }\end{array}$ & $\begin{array}{c}\text { Coefficient } \\
\text { of } \\
\text { dispersion } \\
(\%)\end{array}$ \\
\hline \multicolumn{8}{|c|}{ Municipal income tax SMSAs } \\
\hline \multicolumn{8}{|l|}{ Cincinnati-adopting units } \\
\hline Per capita income tax base & $\$ 11,137$ & $\$ 4,809$ & $\$ 985$ & $\$ 127,119$ & 129 & 8.8 & 175.7 \\
\hline Per capita assessed value & 7,827 & 4,292 & 1,871 & 59.389 & 32 & 4.7 & 114.4 \\
\hline $\begin{array}{l}\text { Per capita income } \\
\quad \text {-all municipalities }\end{array}$ & 5,316 & 4,627 & 2,655 & 14,422 & & & \\
\hline Per capita assessed value & 5,531 & 2,838 & 616 & 59,389 & 96 & 10.9 & 126.4 \\
\hline Per capita income & 4,761 & 4,474 & 1,948 & 14,422 & & & \\
\hline \multicolumn{8}{|l|}{ Cleveland-adopting units } \\
\hline Per capita income tax base & 8,340 & 3,942 & 288 & 195,502 & 679 & 7.7 & 139.5 \\
\hline Per capita assessed value & 8,290 & 4,643 & 2,203 & 212,668 & 97 & 4.4 & 101.1 \\
\hline $\begin{array}{l}\text { Per capita income } \\
\quad \text { - all municipalities }\end{array}$ & 6,259 & 5,630 & 3,925 & 16,062 & & & \\
\hline Per capita assessed value & 7,578 & 4,594 & 1,363 & 212,668 & 156 & 5.2 & 94.3 \\
\hline Per capita income & 6,116 & 5,535 & 3,338 & 16,062 & & & \\
\hline \multicolumn{8}{|c|}{ Municipal sales tax SMSAs } \\
\hline \multicolumn{8}{|l|}{ San Francisco-Oakland } \\
\hline Per capita sales tax base & 11,058 & 2,983 & 226 & 310,757 & 1,376 & 17.8 & 317.4 \\
\hline Per capita assessed value & 7,194 & 4,299 & 1,852 & 129,946 & 70 & 3.7 & 91.2 \\
\hline Per capita income & 6,966 & 5,990 & 4,149 & 15,461 & & & \\
\hline \multicolumn{8}{|l|}{ Los Angeles-Long Beach } \\
\hline Per capita sales tax base & 31,643 & 3,275 & 42 & $1,437,751$ & 34,313 & 59.4 & 907.6 \\
\hline Per capita assessed value & 2,735 & 3,121 & 1,230 & $1,397,214$ & 1,136 & 14.9 & 800.7 \\
\hline Per capita income & 5,640 & 5,277 & 2,785 & 18,069 & & & \\
\hline
\end{tabular}

*Tax base figures are four-year averages; residents' income figures are for 1974.

SOURCE: See text. 
The two largest Ohio SMSAs are included in this study: Cincinnati (Clermont, Hamilton, and Warren Counties) and Cleveland (Cuyahoga, Geauga, Lake, and Medina Counties). The Cincinnati SMSA includes counties in Indiana and Kentucky, and there are some local income taxes there. The non-Ohio counties are excluded, however, because the tax systems to be compared are more similar within a single state and our major data source, a compilation by the Ohio Municipal Leauge [Ohio Municipal League, 1977] covers only Ohio municipalities.

Any one year's income tax data may not be representative due to such factors as timing of receipt of year-end tax payments. For this reason, averages over a four-year period are used; the latest year for which all needed data elements are available is 1975, so 1972-75 is the period used. Also, property tax comparisons after this period are complicated for Ohio by 1976 legislation that created new credits applied after reassessment that alter the linkage between assessed values and tax liabilities. ${ }^{2}$ Income tax base figures for each year were calculated by dividing collections by the tax rate; ${ }^{3}$ four-year-average tax base figures then were calculated. A similar procedure was employed to arrive at property tax base (assessed value) figures based on property tax data in the same Municipal League report. To facilitate comparisons among different-sized municipalities, these average tax bases were converted to per capita amounts by dividing them by 1973 population figures, estimated by the Census Bureau and used for general revenue sharing allocations; 1973 figures came closest of any available to being centered on the study period. In addition, 1974 per capita money income is used in the analyses. ${ }^{4}$ Income tax adoptions have increased in recent years, and some municipalities with an income tax in 1975 did not have one throughout the period. All municipalities with less than two full years' data were eliminated from the study; there were five in all. Those with two or three years' data were included, with the actual averages for those years being used (i.e., no trend adjustment was attempted for the missing years). On this basis, 75 municipalities in the Cleveland SMSA and 30 in the Cincinnati SMSA were included. ${ }^{5}$ There were 89 municipalities in the four-county Cleveland SMSA, and 61 in the three Ohio counties of the Cincinnati SMSA, so the income tax was more universal in the former area than in the latter in the study period. For completeness, however, and to facilitate some comparisons, non-adopting municipalities have been included in some analyses, with data drawn from the above sources (except property value figures were pulled from the tax abstracts filed with the Ohio Department of Tax Equalization).

\section{California Local Sales Taxes}

All areas in California are covered by local 1.25 percent sales and use taxes: 25 percent for county transportation funds and 1 percent for city and county general funds. The general fund portion collected in cities is split between city and county according to local agreement: in 1977, the city component ranged from $85.5 \%$ to $100 \%$ of collections in counties across the state. The taxes are collected simultaneously with the California 
TABLE 3.

Central City-Suburban Comparisons of Per Capita Income of Residents And Per Capita Property and Non-Property Tax Bases for Municipalities In Two Income Tax and Two Sales Tax SMSAs*

\begin{tabular}{|c|c|c|c|}
\hline \multirow[b]{2}{*}{ Municipality or class } & \multicolumn{3}{|c|}{ Median figures-except central cities } \\
\hline & $\begin{array}{l}\text { Per capita } \\
\text { income }\end{array}$ & $\begin{array}{l}\text { Per capita non- } \\
\text { property tax base** }\end{array}$ & $\begin{array}{c}\text { Per capita } \\
\text { assessed value }\end{array}$ \\
\hline \multicolumn{4}{|c|}{ Municipal income tax SMSAs } \\
\hline Cincinnati (city) & $\$ 4,517$ & $\$ 6,436$ & $\$ 4,034$ \\
\hline \multicolumn{4}{|l|}{ Suburban units } \\
\hline -adopting units & 4,693 & 4,800 & 4,345 \\
\hline -all municipalities & 4,473 & - & 2,838 \\
\hline \multicolumn{4}{|l|}{ High-income\# units } \\
\hline _adopting units & 13,348 & 9,370 & 12,725 \\
\hline —all municipalities & 7,945 & - & 4,508 \\
\hline \multicolumn{4}{|l|}{ Low-income\#\# units } \\
\hline —adopting units & 3,463 & 1,398 & 2,378 \\
\hline _all municipalities & 3,195 & - & 1,548 \\
\hline Cleveland (city) & 3,925 & 7,244 & 4,212 \\
\hline \multicolumn{4}{|l|}{ Suburban units } \\
\hline —adopting units & 5,631 & 3,932 & 4,643 \\
\hline —all municipalities & 5,536 & - & 4,595 \\
\hline \multicolumn{4}{|l|}{ High-income\# units } \\
\hline —adopting units & 12,679 & 5,752 & 7,058 \\
\hline all municipalities & 11,924 & - & 6,658 \\
\hline \multicolumn{4}{|l|}{ Low-income\#\# units } \\
\hline —adopting units & 4,416 & 3,501 & 3,398 \\
\hline —all municipalities & 4,311 & - & 2,633 \\
\hline \multicolumn{4}{|c|}{ Municipal sales tax SMSAs } \\
\hline Los Angeles (city) & 5,277 & 3,740 & 3,493 \\
\hline Long Beach (city) & 5,652 & 3,275 & 3,983 \\
\hline Suburban units & 5,242 & 3,143 & 3,115 \\
\hline High-income\# units & 10,913 & 516 & 6,312 \\
\hline Low-income\#\# units & 3,757 & 2,725 & 2,435 \\
\hline San Francisco (city) & 5,990 & 4,714 & 4,408 \\
\hline Oakland (city) & 5,034 & 3,997 & 3,732 \\
\hline Suburban units & 6,042 & 2,888 & 4,299 \\
\hline High-income\# units & 11,967 & 465 & 7,629 \\
\hline Low-income\#\# units & 4,915 & 3,091 & 3,300 \\
\hline
\end{tabular}

*Tax base figures are four-year averages; residents' income figures are for 1974 .

**Income tax base for Cincinnati and Cleveland SMSAs, sales tax base for Los Angeles-Long Beach and San Francisco-Oakland SMSAs.

\#150\% or more of non-central city mean per capita income.

\#\#75\% or less of non-central city mean per capita income.

SOURCE: See text. 
state sales tax and are completely administered by the State Board of Equalization.

A critical choice in the operation of local sales taxes is whether tax liability (and the proceeds resulting from a taxed transaction) is established at the location of a retailer or at the point of delivery to a customer. The latter rule would allow greater consumer support of the community of residence, but would have the complication of requiring sellers to determine tax locations for deliveries (along with the associated audit problem). The retailer location rule simplifies compliance and audit, but potentially creates windfalls for jurisdictions with large retailers or mail order houses. California uses the retailer location rule, the rule most commonly followed across the United States.

The analysis uses data from the two largest California SMSAs: San Francisco-Oakland (San Francisco, Alameda, Contra Costa, Marin, and San Mateo Counties) and Los Angeles-Long Beach (Los Angeles County). The former area contained 58 cities in the period studied; the latter, 77 cities. Data for the analysis come from several issues of the Annual Report of the State Board of Equalization and, as in the Ohio case, from federal revenue sharing entitlement data elements. Four-year-average tax base figures for sales and use (computed by dividing collections by the effective rate) and property taxes were computed, according to the logic developed for the Ohio comparisons, and then converted to per capita amounts using middle-of-period population estimates. These data provide a consistent comparison with the Ohio income tax patterns.

\section{The Evidence}

The data from the sales tax SMSAs (Los Angeles-Long Beach and San Francisco-Oakland) and the income tax SMSAs (Cleveland and Cincinnati) are examined to establish the relative degree of fiscal disparity produced by the major local non-property taxes, compared with the property tax base. Comparisons are made for the total SMSA, for the central cities against their suburbs, for high-income and low-income cities in the area, and-in the Ohio cases-for adopting and all municipalities. The results are reported in Tables 1 to 4 .

A fundamental observation is that the correlation between city assessed value and city non-property tax base per capita is rather high. For the four SMSAs examined, the lowest correlation is 0.95 (Table 1). The various tax handles will thus tend to produce similar gross revenue distributions. It does not hold, however, that per capita income will be closely related to any of the bases because the definitions of tax law often do not match the concepts used for personal income measurement. The correlations between the bases and per capita income are uniformly low and sometimes of negative sign. Some might find startling the almost total lack of correlation between per capita income and the per capita income tax base in the Ohio cities. One must recall, however, that the per capita income figure includes resident income only, while the tax base excludes non-earned income of residents but includes locally-earned income of non-resident commuters and some corporate income. This underscores the risks involved in analysis of hypothetical taxes. 
Table 2 compares the SMSAs according to average per capita property and non-property tax base and presents several measures of disparity among municipalities within each area. The table shows dramatic intrametropolitan ranges of per capita base and high maximum-tominimum ratios for each source. In all four areas, however, the maximum/minimum ratio is greater for the non-property taxes than for the property taxes. Also, the ratios are greater for the sales tax SMSAs than for the income areas. The maximum/minimum ratio, however, may not be the most desirable disparity measure to consider because it is completely outlyer sensitive. A similar, but less sensitive, measure can be computed by comparing the ratio of the fifth city from the top with the fifth city from the bottom. This measure, again presented in Table 2, dramatically reduces the ratios but does not change the general pattern. The assessed value ratio is higher for all municipalities in the Cincinnati SMSA than for the income tax adopting units alone; however, the relevant comparison is between this ratio and that for the income tax base, the second of which cannot be computed for all municipalities. The sales tax ranges still are greater than are those for income taxes and the sales tax ranges remain substantially greater than the comparable property tax ranges. The income tax SMSAs still show greater ranges for the income tax than for the property tax, and the ratios still are far smaller than for the sales tax cities.

A final disparity measure is the coefficient of dispersion for each base, computed according to the formula

$\mathrm{D}=\frac{\sum_{\mathrm{i}=1}^{\mathrm{n}}\left|\mathrm{B}_{1}-\mathrm{M}\right| \frac{.100}{\mathrm{M}}}{\mathrm{n}}$

where $B_{i}=$ the per capita base in unit $\mathrm{i}, \mathrm{M}=$ the median per capita base in the entire metropolitan area, and $n=$ the number of units in the area. Table 2 shows large coefficients of dispersion for all tax bases, but the non-property base coefficient is greater than that of the property base in each area, and the coefficients for the sales taxes are much greater than for the income taxes. Because analysis is from the median, rather than the mean, the coefficients are not extremely sensitive to isolated outlyers. ${ }^{6}$ All measures show substantial disparity of non-property taxes in the metropolitan areas. Reischauer's finding of lesser disparities with an income tax than with a property tax does not hold here, no doubt because his hypothetical income tax was residence-based whereas the Ohio taxes essentially are of the more common employment-based variety.

Table 3 compares the central city in each SMSA with its surrounding suburbs. In the Ohio income tax case, both Cleveland and Cincinnati have a higher per capita income tax base than the median of their suburbs, while having slightly lower assessed value per capita. With the California sales tax cases, Los Angeles, Long Beach, and San Francisco have both sales tax and property tax bases above the suburban median. Oakland has a higher sales 
tax base per capita than do the suburban cities, but its per capita property tax base is lower. Over all the units, however, there is evidence that central cities do fare relatively well with the non-property taxes.

Table 3 also compares high-income and low-income suburban cities in the SMSAs. In each Ohio SMSA, the high-income suburban cities have higher income tax base and property tax base than do the low-income cities; inclusion of municipalities without income taxes does not alter the pattern for the property tax. The pattern for the California cities shows lower per capita assessed value in the lower-income cities. For the sales tax, however, the endowments are reversed, as the high-income cities have dramatically lower sales tax bases per capita than do the low-income units, a result likely produced by the retailer location rule for liability and the absence of large retail outlets in very affluent areas. Within this body of cities, at affluence extremes, the local sales tax provides financing to reverse the pattern found in the property tax.

The previous evidence suggests that municipal non-property taxes in an SMSA show large disparities among cities, and to an extent greater than with their property tax. It is possible, however, that non-property tax base disparity works to counteract property tax disparity. That is, cities with low assessed value per capita may have high non-property tax base per capita, with the result that non-property tax adoption reduces overall fiscal disparity. This possibility does not generally occur. As Table 1 shows, the smallest correlation between the two bases is 0.95 : the pattern of assessed value is largely the pattern of the non-property tax base. Furthermore, in the Ohio SMSAs-where municipal income taxes are not universalmunicipalities that have not opted for the income tax have lower assessed values and incomes per capita than do those with income taxes, more evidence of the practical failure of the non-property taxes to remedy this aspect of disparity. ${ }^{7}$

Table 4 further explores the possibility of disparity reduction by categorizing cities by position above or below SMSA medians on the alternative sources. In the preponderance of instances-San FranciscoOakland the only aberration-the disparity-counteracting effects are minimal: cities with low assessed value have low non-property tax bases and cities with high assessed value have high non-property tax bases. The additional source does not alter the basic disparity problem.

\section{Some Final Observations}

Metropolitan cities are not likely to face dramatically diminished fiscal pressures in the near future. The desire to adopt local non-property taxes for additional services or reduced property tax burdens seems unlikely to be abated. Evidence developed here suggests that, while total metropolitan area fiscal disparities are not likely to be reduced by such taxes, central cities do fare well relative to their suburbs. With respect to suburban cities, sales tax base endowments are relatively higher in the low income cities than in the more affluent ones, contrary to the pattern for either the income tax or the property tax. None should expect a panacea to metropolitan fiscal relationship ills, but the non-property taxes apparently 
TABLE 4.

Distribution Relative To Median Per Capita Property Tax Base And Non-Property Tax Base of Non-Property Tax Municipalities In Two Income Tax and Two Sales Tax SMSAs*

\begin{tabular}{lc}
\hline SMSA and tax distribution category & $\begin{array}{c}\text { Number of } \\
\text { municipalities }\end{array}$ \\
\hline
\end{tabular}

Municipal income tax SMSAs

Cincinnati

$\begin{array}{ll}\text { Both property and non-property bases above median } & 13\end{array}$

$\begin{array}{ll}\text { Both property and non-property bases below median } & 13\end{array}$

Property base below median, non-property base above median

Property base above median, non-property base below median

Cleveland

Both property and non-property bases above median

Both property and non-property bases below median

Property base below median, non-property base above median

Property base above median, non-property base below median

Municipal sales tax SMSAs

Los Angeles-Long Beach

Both property and non-property bases above median

Both property and non-property bases below median

Property base below median, non-property base above median

Property base above median. non-property base below median

San Francisco-Oakland

Both property and non-property bases above median

Both property and non-property bases below median

Property base below median, non-property base above median

Property base above median, non-property base below median

* Tax base figures are four-year averages. Median is categorized in all instances to give benefit of doubt to offsetting disparities.

SOURCE: See text.

have some desirable attributes relative to other options. By increasing disparities throughout the metropolitan area, however, the local nonproperty taxes promise to make the equalization task both more desirable and more expensive. ${ }^{8}$ At the same time, they aid central cities relative to their suburbs. An appropriate policy stance on these fiscal devices may well depend on the facet of metropolitan fiscal problems which is more critical in the particular environment at question. 
The extent to which the findings reported here can be generalized is not known. They emerge from case studies of individual municipalities in four large metropolitan areas. Relationships among municipalities in other areas may differ from those in our four study areas. However, the forms of municipal income and sales taxes used in Ohio and California, respectively, are the most common forms of these major municipal non-property taxes.

It remains a topic for further research why some eligible units in Ohio have not adopted the municipal income tax, compared with the universality of the municipal sales tax in California, and why the non-adopters are generally less affluent in both income and assessed value terms than adopting units.

\section{FOOTNOTES}

1. This change in attitude among public finance scholars and practitioners is reflected by the Advisory Commission on Intergovernmental Relations' (ACIR) 1974 abandonment of its historic opposition to local non-property taxes in favor of qualified support. [ACIR, 1974, pp. 1-4]

2. The rather complex tax reduction process is required pursuant to House Bill 920 in 1976 (Ohio Revised Code, Section 319.301). It is explained in detail in: Percentage Reduction in Taxes Levied by Voted Millage (R.C. 319.301), Bulletin 7, Revised (Columbus: Ohio Department of Tax Equalization, November 1977).

3. Rate changes during a year were adjusted for by using a time-weighted average of the two rates.

4. Office of Revenue Sharing data [U.S. Department of Treasury, 1977a and 1977b] are used for both population and income for both Ohio and California units.

5. Sixty of the 75 , and 25 of the 30 , had four full years' experience. Of the five with less than two years' experience excluded, four were in the Cincinnati area, and one in Cleveland.

6. A comparison of coefficients of variation-based upon (squared) deviations from the mean-produces conclusions that differ somewhat from those emerging from the coefficients of dispersion. The differences are that the Cleveland and the Los AngelesLong Beach property base coefficients are slightly larger than their non-property base coefficients. Basing the calculations on the mean, however, makes the coefficient of variation sensitive to extreme outlyers.
The Cleveland and the Los Angeles-Long Beach SMSAs each have at least one municipality whose per capita tax bases are radically larger than those of other municipalities. Although these extreme outlyers have small populations, they are given equal weighting in the measures of per capita tax base variation. The very high per capita values in these small communities raise the means disproportionately, thereby raising the deviations from the means and the values of the coefficients of variation. Our preference, therefore, is for the coefficient of dispersion, which is based upon deviations from the median, because of its lesser sensitivity to extreme outlyers.

7. The relationships between suburban municipalities with and without income taxes are the following (median per capita figures used):

$\begin{array}{lrr} & \text { Income } & \text { Assessed Value } \\ \text { Cincinnati } & & \\ \text { With income tax } & \$ 4,693 & \$ 4,345 \\ \text { Without income tax } & 3,647 & 1,830 \\ \text { Cleveland } & & \\ \text { With income tax } & 5,631 & 4,643 \\ \text { Without income tax } & 4,246 & 2,355\end{array}$

8. Examination of county-wide local non-property taxes likewise revealed larger disparities with nonproperty taxes than with the property tax in three of the four states examined [Bowman and Mikesell, 1978, 412-422].

\section{REFERENCES}

Advisory Commission on Intergovernmental Relations, 1974. Local Revenue Diversification: Income, Sales Taxes and User Charges, A-47. Washington: U.S. Government Printing Office.

Bowman, John H. and Mikesell, John L. 1978. "Fiscal Disparities and Major Local Non-Property Taxes: Evidence from Revenue Diversification in Indiana, Maryland, Ohio, and Virginia." Proceedings of the Seventieth Annual Conference on Taxation. Columbus, Ohio: National Tax Association-Tax Institute of America: 412-22.

California State Board of Equalization. Various years. Annual Report Sacramento: The Board.

Ohio Department of Tax Equalization. 1972-1976. Unpublished real and tangible personal property abstracts.

Ohio Department of Taxation. 1978a. Municipal Income Taxes: Tax Rates and Amounts Collected, by Municipality, Calendar Year 1976. Columbus: processed.
Ohio Department of Taxation. 1978b. Ohio's Taxes: A Brief Summary of Major State and Local Taxes in Ohio, 1978-1979 Edition. Columbus: The Department.

Ohio Municipal League. 1977. Statistics on Municipal Income Taxes in Ohio, 1977. Columbus: processed.

Reischauer, Robert D. 1975. "In Defense of the Property Tax: The Case Against an Increased Reliance on Local Non-Property Taxes." Proceedings of the Sixty-Seventh Annual Conference on Taxation. Columbus, Ohio: National Tax Association-Tax Institute of America: 288306.

Stephens, G. Ross. 1969. "The Suburban Impact of Earnings Tax Policies." National Tax Journal 22 (September):313-33.

Stocker, Frederick D. 1976. "Diversification of the Local Revenue System: Income and Sales Taxes, User Charges, Federal Grants." National Tax Journal 29(September):312-21. 
U.S. Bureau of the Census. 1980a. Governmental Finances in 1977-78, GF78, No. 5. Washington: U.S. Government Printing Office.

U.S. Bureau of the Census. 1980b. City Government Fimances in 1977-78, GF78, No. 4. Washington: U.S. Government Printing Office.

U.S. Department of Treasury, Office of Revenue Shar- ing. 1977a. General Revenue Sharing State and Local Data Elements, Entitlement Period 7 and Entitlement Period 8. Washington: U.S. Government Printing Office.

U.S. Department of Treasury. Office of Revenue Sharing. 1977b. General Revenue Sharing State and Local Data Elements, Entitlement Period 9. Washington: U.S. Government Printing Office. 